\title{
Publisher Correction: Solvent-assisted programming of flat polymer sheets into reconfigurable and self-healing 3D structures
}

Yang Yang (1) ${ }^{1,2}$, Eugene M. Terentjev (1) ${ }^{2}$, Yen Wei ${ }^{1} \&$ Yan Ji (i) ${ }^{1}$

Correction to: Nature Communications https://doi.org/10.1038/s41467-018-04257-x, published online 15 May 2018

The original version of this Article omitted the Received and Accepted dates; they should have been 21st January 2018 and 12 th April 2018, respectively. This has been corrected in the PDF and HTML versions of the Article.

Published online: 07 June 2018

\begin{abstract}
(c) (i) Open Access This article is licensed under a Creative Commons Attribution 4.0 International License, which permits use, sharing, adaptation, distribution and and indicate if changes were made. The images or other third party material in this article are included in the article's Creative Commons license, unless indicated otherwise in a credit line to the material. If material is not included in the article's Creative Commons license and your intended use is not permitted by statutory regulation or exceeds the permitted use, you will need to obtain permission directly from the copyright holder. To view a copy of this license, visit http://creativecommons.org/licenses/by/4.0/.
\end{abstract}

(C) The Author(s) 2018

\footnotetext{
${ }^{1}$ The Key Laboratory of Bioorganic Phosphorus Chemistry and Chemical Biology (Ministry of Education), Department of Chemistry, Tsinghua University, 100084 Beijing, China. ${ }^{2}$ Cavendish Laboratory, University of Cambridge, CB3 OHE Cambridge, UK. Correspondence and requests for materials should be addressed to Y.J. (email: jiyan@mail.tsinghua.edu.cn)
} 